\title{
Distorted square planar nickel(II) carbonyl complexes containing terminal thiolate/selenolate ligands
}

\author{
Wen-Feng Liaw, ${ }^{* a}$ Chien-Hong Chen, ${ }^{a}$ Chien-Ming Lee, ${ }^{a}$ Gene-Hsiang Lee ${ }^{b}$ \\ and Shie-Ming Peng ${ }^{b}$ \\ ${ }^{a}$ Department of Chemistry, National Changhua University of Education, Changhua 50058, \\ Taiwan.E-mail: chfeng@cc.ncue.edu.tw \\ ${ }^{b}$ Instrumentation Center and Department of Chemistry, National Taiwan University, \\ Taipei 10764, Taiwan
}

\author{
Received 7th November 2000, Accepted 14th November 2000 \\ First published as an Advance Article on the web 21st December 2000
}

\begin{abstract}
Distorted square planar $\left[\mathrm{Ni}(\mathrm{CO})(\mathrm{SR})_{n}(\mathrm{SePh})_{3-n}\right]^{-}\left(\mathrm{n}=0\right.$ (1), 3 (2), 1 (3) or 2 (4); $\mathrm{R}=\mathrm{Ph}$ or $\left.\mathrm{C}_{4} \mathrm{H}_{3} \mathrm{~S}\right)$ complexes, were prepared by unique $\mathrm{Cp}^{-} / \mathrm{PhS}^{-}\left(\mathrm{PhSe}^{-}\right)$exchange reactions and oxidative addition. $\left(\mathrm{SC}_{4} \mathrm{H}_{3} \mathrm{~S}\right)_{2},[\mathrm{NiCp}(\mathrm{CO})]_{2}$ and 2 equivalents of $f a c$ - $\left[\mathrm{N}\left(\mathrm{PPh}_{3}\right)_{2}\right]\left[\mathrm{Fe}(\mathrm{CO})_{3}\left(\mathrm{SC}_{4} \mathrm{H}_{3} \mathrm{~S}\right)_{3}\right]$ in thf led to the isolation of $\left[\mathrm{N}\left(\mathrm{PPh}_{3}\right)_{2}\right]\left[\mathrm{Ni}(\mathrm{CO})\left(\mathrm{SC}_{4} \mathrm{H}_{3} \mathrm{~S}\right)_{3}\right]$ and $\left[\mathrm{FeCp}(\mathrm{CO})_{2}\left(\mathrm{SC}_{4} \mathrm{H}_{3} \mathrm{~S}\right)\right]$. Complex $\left[\mathrm{Ni}^{0}(\mathrm{CO})_{3}(\mathrm{SePh})\right]^{-}$was obtained upon chemical reduction of complex $\left[\mathrm{Ni}(\mathrm{CO})(\mathrm{SePh})_{3}\right]^{-}$with $\left[\mathrm{BH}_{4}\right]^{-}$under a $\mathrm{CO}$ atmosphere in thf. $\left[\mathrm{Ni}^{\mathrm{II}}(\mathrm{CO})(\mathrm{SePh})_{3}\right]^{-}$was reobtained upon oxidative addition of diphenyl diselenide and benzeneselenol to $\left[\mathrm{Ni}^{0}(\mathrm{CO})_{3}(\mathrm{SePh})\right]^{-}$in thf. The mixed-chalcogenolate nickel(II) carbonyl complexes $\left[\mathrm{Ni}(\mathrm{CO})(\mathrm{SPh})_{n}(\mathrm{SePh})_{3-n}\right]^{-}(n=1$ or 2$)$ were prepared by $\mathrm{PhSe}^{-} / \mathrm{PhS}^{-}$ligand exchange reaction and oxidative addition of diphenyl disulfide to $\left[\mathrm{Ni}(\mathrm{CO})_{3}(\mathrm{SePh})\right]^{-}$individually. Complexes $\left[\mathrm{Ni}^{\mathrm{II}}(\mathrm{CO})(\mathrm{SePh})_{3}\right]^{-}$, $\left[\mathrm{Ni}^{\mathrm{II}}\left(\mathrm{SC}_{5} \mathrm{H}_{4} \mathrm{~N}\right)_{3}\right]^{-},\left[\mathrm{Ni}^{0}(\mathrm{CO})_{3}\left(\mathrm{SC}_{5} \mathrm{H}_{4} \mathrm{~N}\right)\right]^{-}$and $\left[\mathrm{Ni}^{0}(\mathrm{CO})_{3}(\mathrm{SePh})\right]^{-}$are chemically interconvertible at ambient temperature. Coordinative addition of the metalloanion $\left[\mathrm{Mn}(\mathrm{CO})_{5}\right]^{-}\left(\left[\mathrm{Fe}(\mathrm{CO})_{4}(\mathrm{SePh})\right]^{-}\right)$to complex $[\mathrm{Ni}(\mathrm{CO})-$ $\left.(\mathrm{SePh})_{3}\right]^{-}$and subsequent redox under a $\mathrm{CO}$ atmosphere led to formation of $\mathrm{cis}-\left[\mathrm{Mn}(\mathrm{CO})_{4}(\mathrm{SePh})_{2}\right]^{-}\left(\mathrm{fac}-\left[\mathrm{Fe}(\mathrm{CO})_{3^{-}}\right.\right.$ $\left.\left.(\mathrm{SePh})_{3}\right]^{-}\right)$and $\left[\mathrm{Ni}^{0}(\mathrm{CO})_{3}(\mathrm{SePh})\right]^{-}$. Nickel(II)/nickel(0) carbonyl thiolate complexes are more unstable thermally than the corresponding carbonyl selenolate complexes. Isotopic shift experiments demonstrate the lability of carbonyl ligand(s) of complexes $\mathbf{1}-\mathbf{4}$ and $\left[\mathrm{Ni}(\mathrm{CO})_{3}(\mathrm{SePh})\right]^{-}$species. The vibrational spectroscopy of the $\mathrm{Ni}^{\mathrm{II}}(\mathrm{CO})$ fragment $\left(v(\mathrm{CO})\right.$ ranges from 2023 to $2043 \mathrm{~cm}^{-1}$ ) found in 1-4 may be regarded as a spectroscopic reference for the carbonyl binding site of $[\mathrm{NiFe}]$ hydrogenases and $\mathrm{CO}$ dehydrogenase.
\end{abstract}

\section{Introduction}

Carbon monoxide dehydrogenase/acetyl-CoA synthase (CODH/ACS) enzymes catalyse the $\mathrm{CO} / \mathrm{CO}_{2}$ interconversion reaction and the acetyl coenzyme $\mathrm{A}$ assembly (thioester acetyl coenzyme A, CoA-SC(O)CH$\left.)_{3}\right){ }^{1}$ Center B is a Fe-S-containing $\left[\mathrm{Fe}_{4} \mathrm{~S}_{4}\right]^{2+/ 1+}$ cluster which is involved in electron transport function. ${ }^{1} \mathrm{CO}$ oxidation occurs at a Ni-FeS-containing center known as center C. Center A responsible for the acetyl-CoA synthesis was proposed to be a Ni-X-Fe $\mathrm{S}_{4}$ structure (bridge $\mathrm{X}$ may be a thiolate or sulfide (unidentified)) and the $\mathrm{CO}$ adduct may serve as a precursor of the carbonyl group of acetyl-CoA. ${ }^{1}$ Center $\mathrm{C}$ is believed to have a closely related structure to that of A. ${ }^{1}$ The oxidation of $\mathrm{CO}$ to $\mathrm{CO}_{2}$ and acetyl-CoA synthesis from $\mathrm{CO}$, a methyl group, and coenzyme A occur at coupled [Ni-X$\mathrm{Fe}$ ] centers, and both nickel and iron have been proposed as binding sites of $\mathrm{CO}^{2,3}$ In combination with EXAFS, EPR, and Mössbauer studies of the Rhodospirillum rubrum enzyme it has been proposed that the nickel environment of center $\mathrm{C}$ adopts a distorted tetrahedral or five-coordinate high-spin state with $2 \mathrm{~S}$ atoms at $2.23 \AA$ and $2-3 \mathrm{~N} / \mathrm{O}$ atoms at $1.87 \AA$, $^{2,4}$ whereas center A from Clostridium thermoaceticum exhibits spectroscopic properties that imply a distorted square planar $\mathrm{Ni}$ surrounded by two S donors and two N/O donors. ${ }^{5}$ A schematic drawing of the proposed $\mathrm{CO}$ binding-site structure of $\mathrm{CO}$ dehydrogenases as deduced from EPR and FTIR studies is shown in Fig. 1. ${ }^{1 a, 4,5}$

There is currently considerable interest in chalcogenolate carbonyl compounds of $\mathrm{Ni}^{\mathrm{II} / \mathrm{I}}$ because of their role as structural/functional models of nickel-containing $\mathrm{CO}$ dehydrogenase enzymes. Very recently, analysis of the XAS spectra

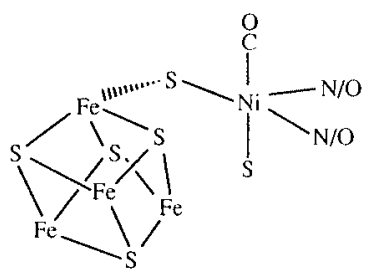

Fig. 1 Schematic drawing of the proposed CO binding-site structure of CO dehydrogenases as deduced from EPR and FTIR studies. ${ }^{1,4,5}$

obtained for the SI-CO complex of Chromatium vinosum hydrogenase revealed the presence of $\left(\mathrm{S}_{\mathrm{cys}}\right)_{2} \mathrm{Ni}\left(\mu-\mathrm{S}_{\mathrm{cys}}\right)_{2} \mathrm{CO}$ ligation, where the $\mathrm{CO}$ is terminally bound to $\mathrm{Ni}^{5 c}$ In spite of the large number of nickel(II) carbonyl complexes known, ${ }^{6}$ in biomimetic chemistry examples of $\mathrm{Ni}^{\mathrm{I}}-\mathrm{CO}$ and $\mathrm{Ni}^{\mathrm{II}}-\mathrm{CO}$ complexes surrounded by biological thiolate/thioether/selenolate ligands are limited. ${ }^{7}$ The five-coordinate nickel(I) chalcogenolate carbonyl complexes $\left[\mathrm{Ni}(\mathrm{DAPA})(\mathrm{EPh})_{2}(\mathrm{CO})\right]^{-}(\mathrm{E}=\mathrm{S}$ or Se; DAPA $=2$, 6-bis[1-(phenylimino)ethyl $]$ pyridine $),{ }^{8}\left[\mathrm{Ni}\left(\mathrm{NS}_{3}{ }^{t}{ }^{-\mathrm{Bu}}\right)\right.$ $(\mathrm{CO})]\left[\mathrm{BPh}_{4}\right]\left(\mathrm{NS}_{3}{ }^{t-\mathrm{Bu}}=\mathrm{N}\left(\mathrm{CH}_{2} \mathrm{CH}_{2} \mathrm{~S}-t-\mathrm{Bu}\right)_{3}\right),{ }^{9}[\mathrm{Ni}(\mathrm{tpttd})(\mathrm{CO})]^{-}$ $\left(\mathrm{H}_{2}\right.$ tpttd $=1,1,10,10$-tetraphenyl-4,7-dithiadecane-1,1-dithiol $),{ }^{10}$ and the five-coordinate nickel(II) thiolate carbonyl complex $[\mathrm{Ni}(\mathrm{PS} 3 *)(\mathrm{CO})]^{-}\left(\mathrm{PS}{ }^{*}=\right.$ tris $(3-$ phenyl-2-sulfanylphenyl)phosphine $){ }^{11}$ and $\left[\mathrm{Ni}\left(\mathrm{PhTt}^{t-\mathrm{Bu}}\right)(\mathrm{CO})_{2}\right] \mathrm{Cl} \quad\left(\mathrm{PhTt}^{t-\mathrm{Bu}}=\right.$ phenyltris(t-butylthiomethyl)borate, $\left.\left(\left(\mathrm{CH}_{3}\right)_{3} \mathrm{SCH}_{2}\right)_{3} \mathrm{BPh}\right)^{7 h}$ were reported. In a previous communication we reported the synthesis and crystal structure of the distorted square planar $\left[\mathrm{Ni}^{\mathrm{II}}(\mathrm{CO})\right.$ $\left.(\mathrm{SePh})_{3}\right]^{-}$prepared by unique $\mathrm{Cp}^{-} / \mathrm{PhSe}^{-}$exchange reactions. ${ }^{12}$

The chemical versatility of sulfur in biology is well established. ${ }^{13 a} \mathrm{~A}$ genetic codon for selenocysteine incorporation 
into proteins has been established in prokaryotes in the past decade. ${ }^{13 b}$ In fact, Böck et al. pronounced selenocysteine as the 21 st amino acid in ribosome-mediated protein synthesis. ${ }^{13 c}$ A logical and significant extension of these efforts would be analogous studies involving exploration of nickel(II) carbonyl derivatives in the biologically relevant thiolate/selenolate ligand field. We have now investigated the reactivity of iron(II) thiolate species $f a c$ - $\left[\mathrm{Fe}(\mathrm{CO})_{3}(\mathrm{SR})_{3}\right]^{-}\left(\mathrm{R}=\mathrm{C}_{4} \mathrm{H}_{3} \mathrm{~S}\right)$ toward $[\mathrm{NiCp}(\mathrm{SR})]_{2}$ and attempted to synthesize nickel(II) thiolate carbonyl complexes by employing $f a c-\left[\mathrm{Fe}(\mathrm{CO})_{3}(\mathrm{SR})_{3}\right]^{-}$as chelating and thiolate ligand-transfer reagent. ${ }^{14}$ Specifically, the syntheses, structures and reactivities of the distorted square planar $\left[\mathrm{Ni}^{\mathrm{II}}\right.$ $\left.(\mathrm{CO})(\mathrm{SR})_{n}(\mathrm{SePh})_{3-n}\right]^{-}(n=0$ (1), $3(\mathbf{2}), 1$ (3) or $2(\mathbf{4}) ; \mathrm{R}=\mathrm{Ph}$ or $\left.\mathrm{C}_{4} \mathrm{H}_{3} \mathrm{~S}\right)$ complexes are described. This study showed that the thermal stability of the nickel-(II)/(0) chalcogenolate carbonyl complexes is dependent upon the nature of the ligands, and $\left[\mathrm{Ni}^{\mathrm{II}}(\mathrm{CO})(\mathrm{SePh})_{3}\right]^{-} \mathbf{1},\left[\mathrm{Ni}^{\mathrm{II}}\left(\mathrm{SC}_{5} \mathrm{H}_{4} \mathrm{~N}\right)_{3}\right]^{-},\left[\mathrm{Ni}^{\mathrm{O}}(\mathrm{CO})_{3}\left(\mathrm{SC}_{5} \mathrm{H}_{4} \mathrm{~N}\right)\right]^{-}$ and $\left[\mathrm{Ni}^{0}(\mathrm{CO})_{3}(\mathrm{SePh})\right]^{-}$are chemically interconvertible at ambient temperature.

\section{Results and discussion}

The synthesis of $\left[\mathrm{Ni}^{\mathrm{II}}(\mathrm{CO})\left(\mathrm{SC}_{4} \mathrm{H}_{3} \mathrm{~S}\right)_{3}\right]^{-} 2$ in a manner analogous to that of $\left[\mathrm{Ni}^{\mathrm{II}}(\mathrm{CO})(\mathrm{SePh})_{3}\right]^{-} \mathbf{1}$ by reaction of $f a c-\left[\mathrm{Fe}(\mathrm{CO})_{3}\right.$ $\left.\left(\mathrm{SC}_{4} \mathrm{H}_{3} \mathrm{~S}\right)_{3}\right]^{-},[\mathrm{NiCp}(\mathrm{CO})]_{2}$, and $\left(\mathrm{SC}_{4} \mathrm{H}_{3} \mathrm{~S}\right)_{2}$ in $2: 1: 1$ stoichiometry was investigated in thf under a nitrogen atmosphere at room temperature. The reaction mixture finally led to the isolation of dark green oily compound $\mathbf{2}$ and the known diethyl ether-soluble green $\left[\mathrm{FeCp}(\mathrm{CO})_{2}\left(\mathrm{SC}_{4} \mathrm{H}_{3} \mathrm{~S}\right)\right]$ on addition of diethyl ether. $^{12,15}$ This result may be accounted for by the following sequences of reaction (Scheme 1); the oxidative addition of

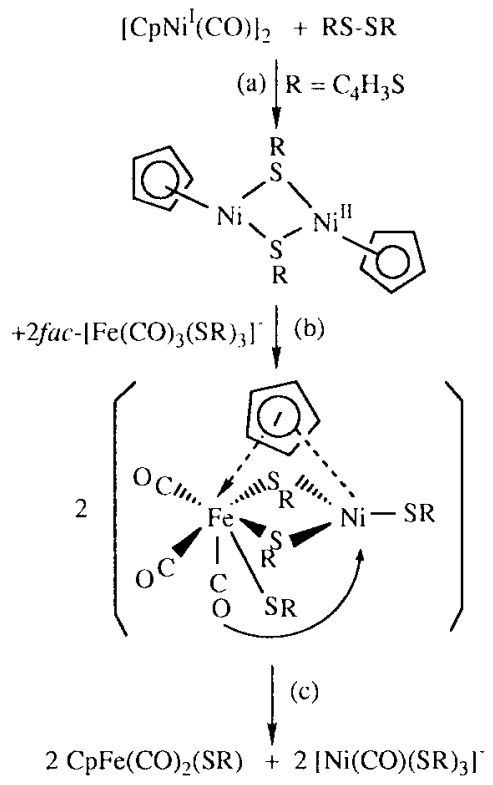

(2)

Scheme 1

$\left(\mathrm{SC}_{4} \mathrm{H}_{3} \mathrm{~S}\right)_{2}$ across the $\mathrm{Ni}-\mathrm{Ni}$ bond (Scheme 1a), ${ }^{16}$ nucleophilic attack of an incoming chelating metallo ligand $\mathrm{fac}-\left[\mathrm{Fe}(\mathrm{CO})_{3^{-}}\right.$ $\left.\left(\mathrm{SC}_{4} \mathrm{H}_{3} \mathrm{~S}\right)_{3}\right]^{-}$accompanied by cyclopentadienyl shift from $\mathrm{Ni}^{\mathrm{II}}$ to $\mathrm{Fe}^{\mathrm{III}},{ }^{17}$ concomitant carbonyl ligand shift from $\mathrm{Fe}^{\mathrm{II}}$ to $\mathrm{Ni}^{\mathrm{II}},{ }^{18}$ and subsequent $\mathrm{Fe}^{\mathrm{II}}-\mathrm{S}$ bond cleavage to give complex 2 and [ $\mathrm{FeCp}$ $\left.(\mathrm{CO})_{2}\left(\mathrm{SC}_{4} \mathrm{H}_{3} \mathrm{~S}\right)\right]$ (Scheme 1b, c). Complex 2 exhibits a IR $v(\mathrm{CO})$ band at $2043 \mathrm{~cm}^{-1}$ (for $\left[\mathrm{N}\left(\mathrm{PPh}_{3}\right)_{2}\right]^{+}$cation and $2050 \mathrm{~cm}^{-1}$ for $\mathrm{Et}_{4} \mathrm{~N}^{+}$cation) which compares well to that $\left(2023 \mathrm{~cm}^{-1}\right)$ of complex 1. The IR spectra of $\mathbf{1}$ and $\mathbf{2}$ in the aprotic solvent thf reveal a strong absorption band for the CO group at 2023 and $2043 \mathrm{~cm}^{-1}$ respectively, within the range observed for the $\mathrm{CODH}-\mathrm{CO}$ complex formed upon incubation of the $C$. thermoaceticum enzyme with ${ }^{12} \mathrm{CO}\left(1995 \mathrm{~cm}^{-1}\right) .{ }^{1 d}$ Also, the $\mathrm{CO}$ ligand lability of complex 2 , as observed in the CODH-CO complex, ${ }^{1 d}$ was demonstrated by exposing a thf solution of 2 to ${ }^{13} \mathrm{CO}$. The IR $v(\mathrm{CO})$ band at $2043 \mathrm{~cm}^{-1}$ shifted to a single absorbance at $1997 \mathrm{~cm}^{-1}$. Following extended periods of stirring in thf at room temperature overnight the dark green thf solution of $\mathbf{2}$ converted into an insoluble solid. Further to add credibility to the proposed mechanism shown in Scheme 1 a similar reaction was conducted. The addition of $f a c-\left[\mathrm{Fe}(\mathrm{CO})_{3}(\mathrm{SePh})_{3}\right]^{-}$to $\left[\mathrm{NiCp}(\mathrm{SePh})\left(\mathrm{PPh}_{3}\right)\right]$ in thf at room temperature led to the formation of complex $1,\left[\mathrm{FeCp}(\mathrm{CO})_{2}(\mathrm{SePh})\right]$ (major products), and $c i s-\left[\mathrm{Ni}(\mathrm{CO})_{2}\left(\mathrm{PPh}_{3}\right)_{2}\right],\left[\mathrm{Ni}(\mathrm{CO})_{3}\left(\mathrm{PPh}_{3}\right)\right]$ (minor products) identified by IR. ${ }^{19}$

In order to synthesize nickel(II) mixed-chalcogenolate carbonyl complexes and evaluate the influence of the chalcogenolate $\left(\mathrm{RSe}^{-} / \mathrm{RS}^{-}\right.$) ligands on the stability and reactivity of the $\left[\mathrm{Ni}(\mathrm{CO})(\mathrm{ER})_{3}\right]^{-}$complexes $(\mathrm{E}=\mathrm{S}$ or $\mathrm{Se})$, a straightforward synthetic reaction of complex 1 with 1 equivalent of $(\mathrm{PhS})_{2}$ in thf was conducted. This resulted in the formation of airsensitive dark green $\left[\mathrm{Ni}(\mathrm{CO})(\mathrm{SPh})(\mathrm{SePh})_{2}\right]^{-} 3$ under $\mathrm{N}_{2}$ at $25^{\circ} \mathrm{C}$. In addition to the X-ray analysis and the UV-visible spectrum, a higher $v(\mathrm{CO})\left(2029 \mathrm{~cm}^{-1}\right)$ compared to that of $\mathbf{1}$ $\left(2023 \mathrm{~cm}^{-1}\right)$ also supports the formation of complex 3. From these results it can be concluded that replacement of benzeneselenolate with thiolate ligand in complex $\mathbf{1}$ has a significant effect on its thermal stability and sensitivity toward air.

The complex $\left[\mathrm{Ni}^{0}(\mathrm{CO})_{3}(\mathrm{SePh})\right]^{-}$was obtained upon chemical reduction of 1 with $\left[\mathrm{N}\left(\mathrm{PPh}_{3}\right)_{2}\right]\left[\mathrm{BH}_{4}\right]$ ([sodium-benzophenone$\left.\mathrm{LiMe} \cdot \mathrm{OEt}_{2}\right)$ under $\mathrm{CO}$ in thf $(\mathrm{MeCN})$ at ambient temperature (Scheme 2a). IR ((thf): $v(\mathrm{CO}) 1944 \mathrm{vs,} 2031 \mathrm{w} \mathrm{cm}{ }^{-1}$ ) and ${ }^{13} \mathrm{C}$

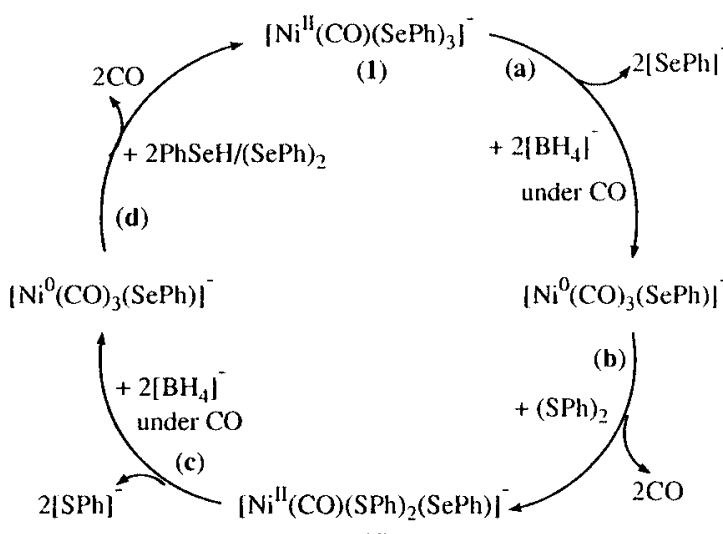

(4)

Scheme 2

NMR ( $\left.\delta 199.72(\mathrm{~s})(\mathrm{CO})\left(\mathrm{CD}_{3} \mathrm{CN}\right)\right)$ studies confirmed the formation of dark green oily $\left[\mathrm{Ni}^{3}(\mathrm{CO})_{3}(\mathrm{SePh})\right]^{-} .^{19,20} \mathrm{The}\left[\mathrm{BH}_{4}\right]^{-}$ and $\mathrm{LiMe} \cdot \mathrm{OEt}_{2}$ serve as reductants in these reactions. Binding $\mathrm{H}^{-} / \mathrm{R}^{-}$groups to $\mathrm{Ni}^{\mathrm{II}}-\mathrm{CO}$ was not observed spectrally (by IR) at $0{ }^{\circ} \mathrm{C}$. Following extended periods of stirring at room temperature, a thf solution of $\left[\mathrm{Ni}^{0}(\mathrm{CO})_{3}(\mathrm{SePh})\right]^{-}$converted into $\mathrm{Ni}(\mathrm{CO})_{4}$ and, presumably, $\left[\mathrm{N}\left(\mathrm{PPh}_{3}\right)_{2}\right][\mathrm{SePh}]$. Ni(CO) $)_{4}$ was identified by its IR $v(\mathrm{CO})$ band at $2043 \mathrm{~cm}^{-1}$ (thf). ${ }^{7 c}$ Alkylation of $\left[\mathrm{Ni}(\mathrm{CO})_{3}(\mathrm{SePh})\right]^{-}$by $\left[\mathrm{Et}_{3} \mathrm{O}\right]\left[\mathrm{BF}_{4}\right]$ led to formation of $\mathrm{Ni}(\mathrm{CO})_{4}$ and $\mathrm{PhSeEt}$ identified by ${ }^{1} \mathrm{H}$ NMR. Indeed the complex $\left[\mathrm{Ni}(\mathrm{CO})_{3}(\mathrm{SePh})\right]^{-}$undergoes a clean ligand exchange process with ${ }^{13} \mathrm{C}$-labeled carbon monoxide in thf to afford ${ }^{13} \mathrm{C}$-enriched derivatives $\left[\mathrm{Ni}\left({ }^{13} \mathrm{CO}\right)_{3}(\mathrm{SePh})\right]^{-}\left(v(\mathrm{CO}) 1900 \mathrm{vs}, 1984 \mathrm{~m} \mathrm{~cm} \mathrm{~cm}^{-1}\right.$ close to $1944 \mathrm{vs}, 2031 \mathrm{~m} \mathrm{~cm}^{-1}$ for $\left[\mathrm{Ni}\left({ }^{12} \mathrm{CO}\right)_{3}(\mathrm{SePh})\right]^{-}$as expected on the basis of the difference in mass between ${ }^{12} \mathrm{C}$ and ${ }^{13} \mathrm{C}$ ). Oxidative addition of diphenyl disulfide to coordinatively unsaturated, low-valent, anionic $\left[\mathrm{Ni}^{0}(\mathrm{CO})_{3}(\mathrm{SePh})\right]^{-}$results in formation of $\left[\mathrm{Ni}^{\mathrm{II}}(\mathrm{CO})(\mathrm{SPh})_{2}(\mathrm{SePh})\right]^{-} 4$ (Scheme $\left.2 \mathrm{~b}\right)$. Complexes 3 and 4, individually, exhibit a one-band pattern in the $v_{\text {Co }}$ region of the infrared, but different positions, $v_{\text {CO }} 2029$ $\mathrm{cm}^{-1}$ (thf) for 3 and $2034 \mathrm{~cm}^{-1}$ (thf) for $\mathbf{4}$, which is consistent with the distinct electronic effects of benzene-selenolate and -thiolate ligands. Complex $\mathbf{4}$ was formed as a crystalline solid in 
good yield after recrystallization from thf-hexane. Its structure determined by X-ray crystallography shows that it is isostructural with complexes $\mathbf{1}$ and $\mathbf{3}$.

IR $v(\mathrm{CO})$ spectra revealed that $\left[\mathrm{Ni}^{0}(\mathrm{CO})_{3}(\mathrm{SePh})\right]^{-}$was reobtained when adding 2 equivalents of $\left[\mathrm{N}\left(\mathrm{PPh}_{3}\right)_{2}\right]\left[\mathrm{BH}_{4}\right]$ to complex 4 under a $\mathrm{CO}$ atmosphere in thf $(\mathrm{MeCN})$ solution (Scheme 2c). Apparently, the metal-centered reduction of 4 labilizes the $[\mathrm{SPh}]^{-}$ligands and results in formation of $\left[\mathrm{Ni}^{0}(\mathrm{CO})_{3}(\mathrm{SePh})\right]^{-}$. The loss of the $[\mathrm{SPh}]^{-}$ligands from the $\mathrm{Ni}^{0}$ may be due to the rich electron density around the nickel(0) center and the more stable nickel(0) carbonyl selenolate compound. ${ }^{21}$

Complex 1 was reobtained upon oxidative addition of diphenyl diselenide and benzeneselenol to $\left[\mathrm{Ni}(\mathrm{CO})_{3}(\mathrm{SePh})\right]^{-}$in thf respectively (Scheme $2 \mathrm{~d}$ ). The reaction presumably involved oxidative addition of $\mathrm{PhSe}-\mathrm{H}$ to $\left[\mathrm{Ni}^{0}(\mathrm{CO})_{3}(\mathrm{SePh})\right]^{-}$to yield the nickel(II) hydride intermediate $\left[\mathrm{Ni}^{\mathrm{II}}(\mathrm{H})(\mathrm{CO})_{2}(\mathrm{SePh})_{2}\right]^{-}$, and subsequent acid-base reaction $\left(\mathrm{PhSe}-\mathrm{H}\right.$ and $\left[\mathrm{Ni}^{\mathrm{II}}(\mathrm{H})(\mathrm{CO})_{2}-\right.$ $\left.\left.(\mathrm{SePh})_{2}\right]^{-}\right)$to form complex 1 with evolution of $\mathrm{H}_{2}$ gas. ${ }^{22}$ Attempts to trap the potential intermediate spectrally (by IR and ${ }^{1} \mathrm{H}$ NMR) were unsuccessful.

In a similar fashion, the ligand-displacement reaction was also displayed by complex 1 and bis(2-pyridyl) disulfide. When a thf solution of 1 was treated with 2 equivalents of bis(2pyridyl) disulfide an immediate change from dark green to dark brown was observed. The ${ }^{1} \mathrm{H}$ NMR spectrum ( $\delta 96.47$ (br), 70.10 (br), 53.73 (br), 12.27 (br)) indicated formation of the known $\mathrm{d}^{8}$ paramagnetic tris-chelate complex $\left[\mathrm{Ni}^{\mathrm{II}}\left(\mathrm{SC}_{5} \mathrm{H}_{4} \mathrm{~N}\right)_{3}\right]^{-}$ (Scheme 3a). ${ }^{23}$

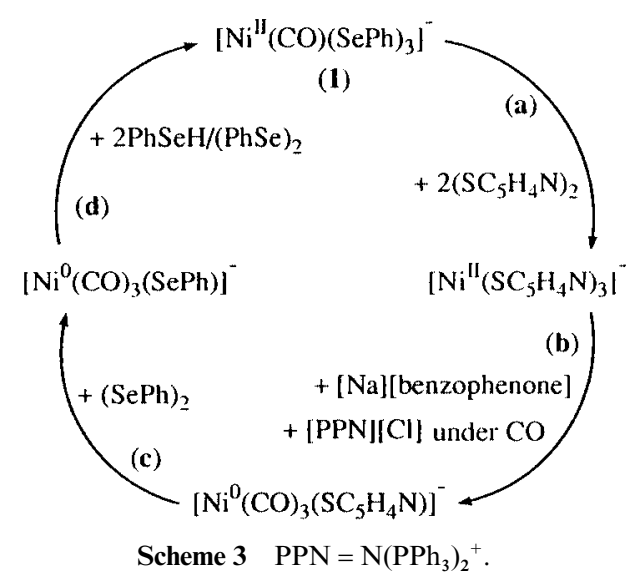

The ring-opened complex $\left[\mathrm{Ni}^{0}(\mathrm{CO})_{3}\left(\mathrm{SC}_{5} \mathrm{H}_{4} \mathrm{~N}\right)\right]^{-}$(IR (thf): $v(\mathrm{CO}) 2037 \mathrm{w}, 1951 \mathrm{~s} \mathrm{~cm} \mathrm{~cm}^{-1}$; monodentate, S-bonded) was obtained upon chemical reduction of $\left[\mathrm{Ni}^{\mathrm{II}}\left(\mathrm{SC}_{5} \mathrm{H}_{4} \mathrm{~N}\right)_{3}\right]^{-}$with sodium-benzophenone under a $\mathrm{CO}$ atomosphere in thf at room temperature (Scheme $3 b){ }^{20}$ Here the metal-centered reduction of $\left[\mathrm{Ni}^{\mathrm{II}}\left(\mathrm{SC}_{5} \mathrm{H}_{4} \mathrm{~N}\right)_{3}\right]^{-}$labilizes the chelating ligands $\left[\mathrm{SC}_{5} \mathrm{H}_{4} \mathrm{~N}\right]^{-}$and results in formation of the four-coordinate species $\left[\mathrm{Ni}^{0}(\mathrm{CO})_{3}\left(\mathrm{SC}_{5} \mathrm{H}_{4} \mathrm{~N}\right)\right]^{-}$. Upon addition of 1 equivalent of diphenyl diselenide to $\left[\mathrm{Ni}^{0}(\mathrm{CO})_{3}\left(\mathrm{SC}_{5} \mathrm{H}_{4} \mathrm{~N}\right)\right]^{-}$the bands at $2037 \mathrm{w}, 1951 \mathrm{~s} \mathrm{~cm}^{-1}$ disappeared, with concomitant formation of a spectrum $\left(v(\mathrm{CO}) 2031 \mathrm{w}, 1944 \mathrm{~s} \mathrm{~cm} \mathrm{~cm}^{-1}\right)$ assigned to $\left[\mathrm{Ni}(\mathrm{CO})_{3}(\mathrm{SePh})\right]^{-}($Scheme $3 \mathrm{c})$. The results suggest that the selenolate ligand enhances the stability of nickel( 0 ) complexes. Complex 1 was reobtained upon addition of diphenyl diselenide to $\left[\mathrm{Ni}(\mathrm{CO})_{3}(\mathrm{SePh})\right]^{-}$in thf (Scheme 3d). Apparently, anionic 1, $\left[\mathrm{Ni}^{\mathrm{II}}\left(\mathrm{SC}_{5} \mathrm{H}_{4} \mathrm{~N}\right)_{3}\right]^{-},\left[\mathrm{Ni}^{0}(\mathrm{CO})_{3}\left(\mathrm{SC}_{5} \mathrm{H}_{4} \mathrm{~N}\right)\right]^{-}$and $\left[\mathrm{Ni}^{0}-\right.$ $\left.(\mathrm{CO})_{3}(\mathrm{SePh})\right]^{-}$are chemically interconvertible at ambient temperature.

Additionally, when a thf solution of 1 equivalent of $\left[\mathrm{N}\left(\mathrm{PPh}_{3}\right)_{2}\right]\left[\mathrm{Mn}(\mathrm{CO})_{5}\right]$ and 1 equivalent of complex $\mathbf{1}$ is stirred under $\mathrm{CO}$ a rapid reaction ensues over the course of 5 min at ambient temperature to give $\left[\mathrm{Ni}(\mathrm{CO})_{3}(\mathrm{SePh})\right]^{-}$and cis$\left[\mathrm{Mn}(\mathrm{CO})_{4}(\mathrm{SePh})_{2}\right]^{-}$, as evident from their IR and NMR spectra

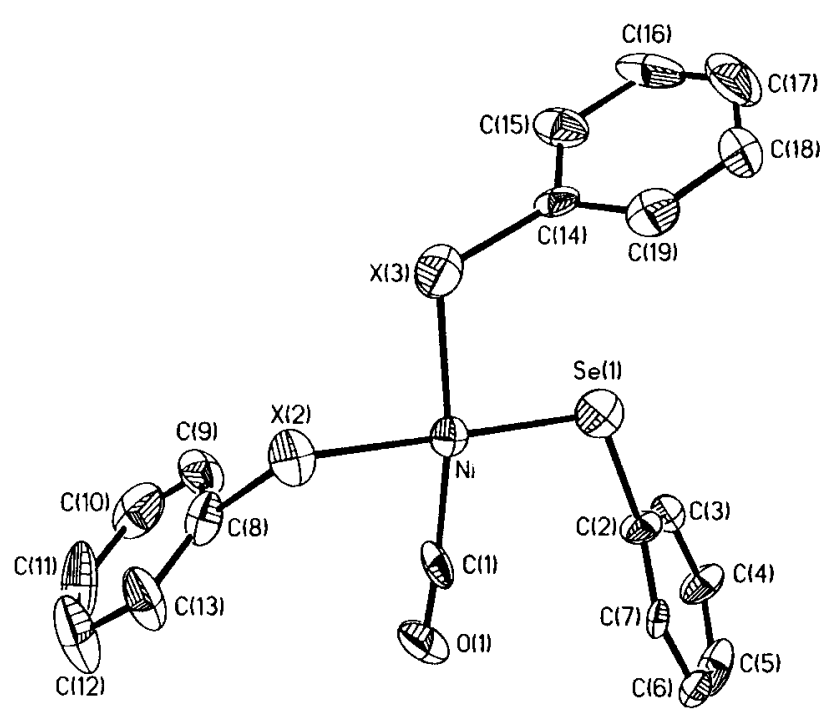

Fig. 2 An ORTEP ${ }^{26}$ drawing and labeling scheme of the [Ni(CO)$\left.(\mathrm{SPh})(\mathrm{SePh})_{2}\right]^{-}$anion with thermal ellipsoids drawn at $30 \%$ probability $(\mathrm{X} 2=0.605 \mathrm{Se}+0.395 \mathrm{~S} ; \mathrm{X} 3=0.395 \mathrm{Se}+0.605 \mathrm{~S})$.

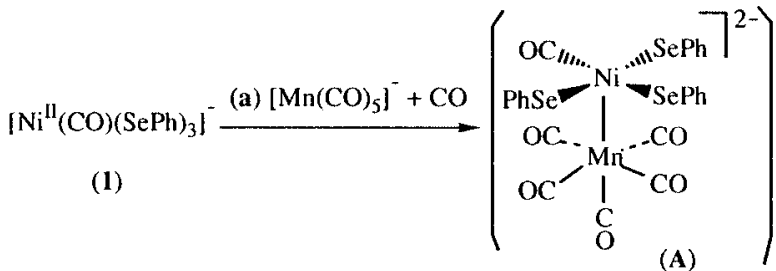

$$
\begin{aligned}
& \text { (b) } \\
& \operatorname{cis}-\left[\mathrm{Mn}(\mathrm{CO})_{4}(\mathrm{SePh})_{2}\right]^{-}+\left[\mathrm{Ni}^{\circ}(\mathrm{CO})_{3}(\mathrm{SePh})\right]^{\circ}
\end{aligned}
$$

reported in this paper for $\left[\mathrm{Ni}(\mathrm{CO})_{3}(\mathrm{SePh})\right]^{-}$and earlier (IR and X-ray diffraction) for cis-[Mn $\left.(\mathrm{CO})_{4}(\mathrm{SePh})_{2}\right]^{-}$(Scheme 4a,b). ${ }^{18}$ This result can be interpreted as coordinative addition of the metalloanion $\left[\mathrm{Mn}(\mathrm{CO})_{5}\right]^{-}$to $\mathbf{1}$ and subsequent redox ligand transfer to give $c i s-\left[\mathrm{Mn}(\mathrm{CO})_{4}(\mathrm{SePh})_{2}\right]^{-}$and $\left[\mathrm{Ni}^{0}(\mathrm{CO})_{3}(\mathrm{SePh})\right]^{-},{ }^{18}$ since the $\left[\mathrm{Mn}(\mathrm{CO})_{5}\right]^{-}$anion has been shown to serve as a lonepair-electron donor. ${ }^{24}$ The presumed intermediate $\mathbf{A}$ was not detected spectrally.

Under similar reaction conditions, addition of $\left[\mathrm{Fe}(\mathrm{CO})_{4^{-}}\right.$ $(\mathrm{SePh})]^{-}$to complex 1 under a $\mathrm{CO}$ atmosphere in thf also resulted in formation of $f a c-\left[\mathrm{Fe}(\mathrm{CO})_{3}(\mathrm{SePh})_{3}\right]^{-}$and $\left[\mathrm{Ni}^{0}(\mathrm{CO})_{3}-\right.$ $(\mathrm{SePh})]^{-}{ }^{25}$ The ligands $[\mathrm{SePh}]^{-}$were not observed to undergo oxidation and decomposition in the above two redox processes, and consequently the redox processes were assigned to the $\mathrm{Ni}^{\mathrm{II}} \mathrm{Mn}^{-\mathrm{I}}-\mathrm{Ni}^{0} \mathrm{Mn}^{\mathrm{I}}$ and $\mathrm{Ni}^{\mathrm{II}} \mathrm{Fe}^{0}-\mathrm{Ni}^{0} \mathrm{Fe}^{\mathrm{II}}$ couples respectively.

The molecular structure of complex $\mathbf{3}$ is depicted in Fig. 2. Selected bond distances and angles for $\mathbf{3}$ and $\mathbf{4}$ are given in Table 1. The complexes 3 and $\mathbf{4}$ consist of discrete $\left[\mathrm{N}\left(\mathrm{PPh}_{3}\right)_{2}\right]^{+}$ cations and $\left[\mathrm{Ni}(\mathrm{CO})(\mathrm{SPh})(\mathrm{SePh})_{2}\right]^{-} /\left[\mathrm{Ni}(\mathrm{CO})(\mathrm{SPh})_{2}(\mathrm{SePh})\right]^{-}$ anions individually. Disorder in the structure of $\mathbf{3}$ prevents detailed determinations of $\mathrm{Ni}^{\mathrm{II}}-\mathrm{S}$ and $\mathrm{Ni}^{\mathrm{II}}-\mathrm{Se}$ bond distances. Bond angles (Se(1)-Ni-X(2) 174.65(12), $\mathrm{Se}(1)-\mathrm{Ni}-\mathrm{C}(1)$ 94.8(4) ${ }^{\circ}, \quad \mathrm{X}(3)-\mathrm{Ni}-\mathrm{C}(1) \quad 171.6(5)^{\circ}, \quad$ and $\quad \mathrm{Se}(1)-\mathrm{Ni}-\mathrm{X}(3)$ 93.01(12) ${ }^{\circ}$ ) around the $\mathrm{Ni}^{\mathrm{II}}$ define a distorted square planar coordination sphere. The $\mathrm{Ni}^{\mathrm{II}}-\mathrm{Se}(1)$ bond length of 2.270(3) $\AA$ is significantly shorter than the $\mathrm{Ni}^{\mathrm{II}}-\mathrm{Se}$ bond length of $2.317(2)$ $\AA$ (average) in $1 .{ }^{12}$ The anionic complex 4 is isostructural with 3 (Fig. 3). Owing to disorder, the exact $\mathrm{Ni}-\mathrm{S}, \mathrm{Ni}-\mathrm{Se}$ bond distances are poorly determined in 4 . The $\mathrm{Ni}^{\mathrm{II}}-\mathrm{X}$ bond length of 2.264(1) $\AA$ (average) is comparable to the $\mathrm{Ni}^{\mathrm{II}}-\mathrm{S}$ bond length of $2.281(1) \AA$ in $\left[\mathrm{Ni}\left(\mathrm{SC}_{6} \mathrm{H}_{4} \mathrm{Cl}-p\right)_{4}\right]^{2-}{ }^{27}$ The $\mathrm{Ni}{ }^{\mathrm{II}}-\mathrm{CO}$ bond lengths $1.80(2)$ and $1.737(5) \AA$ in $\mathbf{3}$ and $\mathbf{4}$ respectively, well within the range observed for other nickel(II) carbonyl 


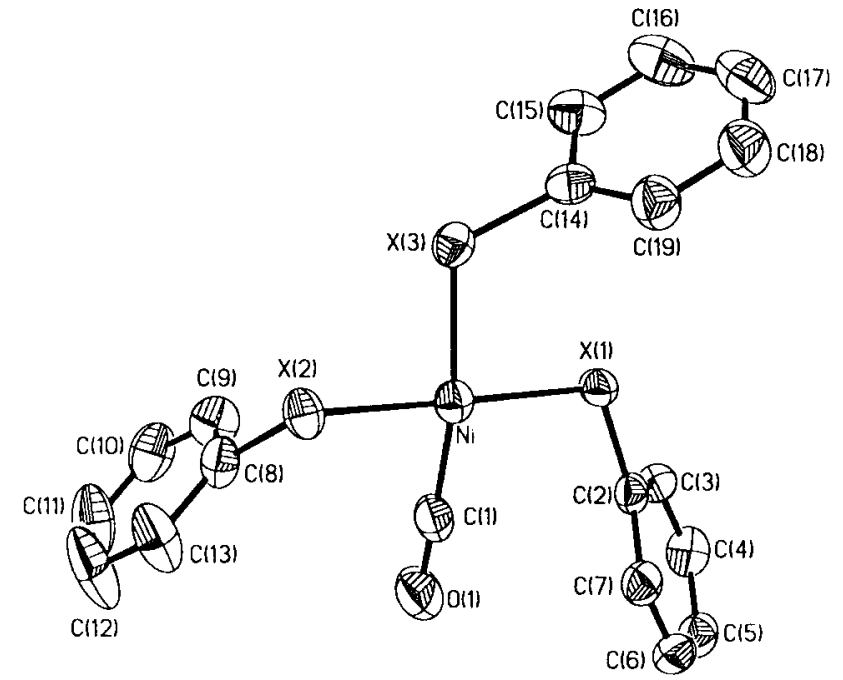

Fig. 3 An ORTEP drawing and labeling scheme of the $\left[\mathrm{Ni}(\mathrm{CO})(\mathrm{SPh})_{2}\right.$ $(\mathrm{SePh})]^{-}$anion with thermal ellipsoids drawn at $30 \%$ probability $(\mathrm{X} 1=0.46 \mathrm{Se}+0.54 \mathrm{~S} ; \mathrm{X} 2=0.40 \mathrm{Se}+0.60 \mathrm{~S} ; \mathrm{X} 3=0.14 \mathrm{Se}+0.86 \mathrm{~S})$.

Table 1 Selected bond distances $(\AA)$ and angles $\left({ }^{\circ}\right)$ for complexes 3 and 4

\begin{tabular}{lclc}
\hline Complex 3 & & & \\
$\mathrm{Ni}-\mathrm{Se}(1)$ & $2.270(3)$ & $\mathrm{Ni}-\mathrm{X}(2)$ & $2.304(3)$ \\
$\mathrm{Ni}-\mathrm{X}(3)$ & $2.237(3)$ & $\mathrm{Ni}-\mathrm{C}(1)$ & $1.80(2)$ \\
$\mathrm{C}(1)-\mathrm{O}(1)$ & $1.09(2)$ & & \\
& & & \\
$\mathrm{Se}(1)-\mathrm{Ni}-\mathrm{X}(2)$ & $174.65(12)$ & $\mathrm{Se}(1)-\mathrm{Ni}-\mathrm{X}(3)$ & $93.01(12)$ \\
$\mathrm{Se}(1)-\mathrm{Ni}-\mathrm{C}(1)$ & $94.8(4)$ & $\mathrm{X}(2)-\mathrm{Ni}-\mathrm{X}(3)$ & $84.62(11)$ \\
$\mathrm{X}(2)-\mathrm{Ni}-\mathrm{C}(1)$ & $87.8(4)$ & $\mathrm{X}(3)-\mathrm{Ni}-\mathrm{C}(1)$ & $171.6(5)$ \\
$\mathrm{Ni}-\mathrm{C}(1)-\mathrm{O}(1)$ & $174.2(14)$ & & \\
& & & \\
$\mathrm{Complex} 4$ & & & \\
$\mathrm{Ni}-\mathrm{X}(3)$ & $2.228(1)$ & $\mathrm{Ni}-\mathrm{X}(1)$ & \\
$\mathrm{Ni}-\mathrm{X}(2)$ & $2.300(1)$ & $\mathrm{Ni}-\mathrm{C}(1)$ & \\
$\mathrm{C}(1)-\mathrm{O}(1)$ & $1.137(5)$ & & $8.737(5)$ \\
& & & \\
$\mathrm{X}(3)-\mathrm{Ni}-\mathrm{X}(1)$ & $92.75(4)$ & $\mathrm{X}(3)-\mathrm{Ni}-\mathrm{X}(2)$ & $84.65(4)$ \\
$\mathrm{X}(3)-\mathrm{Ni}-\mathrm{C}(1)$ & $170.51(14)$ & $\mathrm{X}(1)-\mathrm{Ni}-\mathrm{X}(2)$ & $174.47(3)$ \\
$\mathrm{X}(1)-\mathrm{Ni}-\mathrm{C}(1)$ & $96.20(14)$ & $\mathrm{X}(2)-\mathrm{Ni}-\mathrm{C}(1)$ & $86.7(2)$ \\
$\mathrm{Ni}-\mathrm{C}(1)-\mathrm{O}(1)$ & $178.2(4)$ & & \\
\hline
\end{tabular}

complexes $(1.73-1.83 \AA),{ }^{6}$ are comparable to the value $1.75(3) \AA$ in $\left[\mathrm{Ni}\left(\mathrm{PS}^{*}\right)(\mathrm{CO})\right]^{-},{ }^{11}$ and shorter than the $\mathrm{Ni}^{\mathrm{I}}-\mathrm{CO}$ bond distance $(1.81(1) \AA)$ observed for $\left[\mathrm{Ni}\left(\mathrm{NS}_{3}{ }^{t}{ }^{t \mathrm{Bu}}\right)(\mathrm{CO})\right]\left[\mathrm{BPh}_{4}\right] .{ }^{9}$ The longer $\mathrm{Ni}^{\mathrm{II}}-\mathrm{CO}$ bond distances (in 3 and $\mathbf{4}$ ) compared with that $(1.729 \AA)$ in $\mathbf{1}$ are ascribed to the weaker $\sigma$-donating ability of benzenethiolate.

\section{Conclusion}

The following are the principal results of this study.

1 The distorted square planar complex $\left[\mathrm{Ni}^{\mathrm{II}}(\mathrm{CO})(\mathrm{SR})_{3}\right]^{-}$ $\left(\mathrm{R}=\mathrm{C}_{4} \mathrm{H}_{3} \mathrm{~S}\right.$ ) with a $\mathrm{Ni}^{\mathrm{II}}-\mathrm{CO}$ bond has been prepared by reaction of $2 f a c-\left[\mathrm{Fe}(\mathrm{CO})_{3}(\mathrm{SR})_{3}\right]^{-},(\mathrm{RS})_{2}$, and $[\mathrm{NiCp}(\mathrm{CO})]_{2}$. The mixed-chalcogenolate nickel(II) carbonyl complexes [Ni(CO)$\left.(\mathrm{SePh})_{n}(\mathrm{SPh})_{3-n}\right]^{-}(n=2$ or 1$)$ are prepared by $\mathrm{PhSe}^{-} / \mathrm{PhS}^{-}$ ligand exchange reaction and oxidative addition of diphenyl disulfide to $\left[\mathrm{Ni}(\mathrm{CO})_{3}(\mathrm{SePh})\right]^{-}$respectively.

2 Nickel(II)/nickel(0) carbonyl thiolate complexes are more unstable thermally than the corresponding carbonyl selenolate complexes. This result may be accounted for by the distinct electronic effects of selenolate and thiolate ligands. In brief, the electronic effect plays an important role in stabilizing the nickel(II) carbonyl chalcogenolate complexes.

3 Isotopic shift experiments demonstrate the lability of carbonyl ligand(s) of $\left[\mathrm{Ni}(\mathrm{CO})(\mathrm{SePh})_{n}(\mathrm{SR})_{3-n}\right]^{-}(n=3,2,1$ or 0$)$ and $\left[\mathrm{Ni}(\mathrm{CO})_{3}(\mathrm{SePh})\right]^{-}$species.
4 Complexes 1-4 are easily reduced to the nickel(0) tricarbonyl chalcogenolate species with reductants like $\left[\mathrm{BH}_{4}\right]^{-/}$ sodium-benzophenone in thf.

$5\left[\mathrm{Ni}^{\mathrm{II}}(\mathrm{CO})(\mathrm{SePh})_{3}\right]^{-},\left[\mathrm{Ni}^{\mathrm{II}}\left(\mathrm{SC}_{5} \mathrm{H}_{4} \mathrm{~N}\right)_{3}\right]^{-}, \quad\left[\mathrm{Ni}^{0}(\mathrm{CO})_{3}\left(\mathrm{SC}_{5} \mathrm{H}_{4^{-}}\right.\right.$ $\mathrm{N})]^{-}$and $\left[\mathrm{Ni}^{0}(\mathrm{CO})_{3}(\mathrm{SePh})\right]^{-}$are chemically interconvertible at ambient temperature.

6 Redox and subsequent ligand transfer lead to the formation of $\left[\mathrm{Ni}^{0}(\mathrm{CO})_{3}(\mathrm{SePh})\right]^{-}$and $c i s-\left[\mathrm{Mn}(\mathrm{CO})_{4}(\mathrm{SePh})_{2}\right]^{-}\left(f a c-\left[\mathrm{Fe}(\mathrm{CO})_{3^{-}}\right.\right.$ $\left.\left.(\mathrm{SePh})_{3}\right]^{-}\right)$from $\left[\mathrm{Ni}^{\mathrm{II}}(\mathrm{CO})(\mathrm{SePh})_{3}\right]^{-}$and $\left[\mathrm{Mn}(\mathrm{CO})_{5}\right]^{-}\left(\left[\mathrm{Fe}(\mathrm{CO})_{4^{-}}\right.\right.$ $\left.(\mathrm{SePh})]^{-}\right)$individually.

7 The vibrational spectra of the $\mathrm{Ni}^{\mathrm{II}}(\mathrm{CO})$ fragment $(v(\mathrm{CO})$ ranges from 2023 to $2043 \mathrm{~cm}^{-1}$ ) found for complexes 1-4 may be regarded as a spectroscopic reference for the carbonyl binding site of $\mathrm{CO}$ dehydrogenase. ${ }^{1 d}$

8 All attempts to bind both $\mathrm{R}(\mathrm{H}$ or $\mathrm{Me})$ and $\mathrm{CO}$ ligands to $\mathrm{Ni}^{\mathrm{II}}$ simultaneously were not observed spectrally (by IR). This may support the existence of two binding sites for transient binding of both $\mathrm{CO}$ and the alkyl ligands in CODH/ACS. ${ }^{1-4,8,9}$

\section{Experimental}

Manipulations, reactions, and transfers of samples were conducted under nitrogen according to standard Schlenk techniques or in a glove-box (argon gas). Solvents were distilled under nitrogen from appropriate drying agents (diethyl ether from $\mathrm{CaH}_{2}$; acetonitrile from $\mathrm{CaH}_{2}-\mathrm{P}_{2} \mathrm{O}_{5}$; methylene chloride from $\mathrm{P}_{2} \mathrm{O}_{5}$; hexane and tetrahydrofuran (thf) from sodiumbenzophenone) and stored in dried, $\mathrm{N}_{2}$-filled flasks over $4 \AA$ molecular sieves. Nitrogen purge was used on these solvents before use and transfers to reaction vessels were via stainless steel cannula under a positive pressure of $\mathrm{N}_{2}$. The reagents iron pentacarbonyl, bis(triphenylphosphoranylidene)ammonium chloride, diphenyl diselenide, di(2-thienyl) disulfide, diphenyl disulfide, bis(2-pyridyl) disulfide (Aldrich/Lancaster) were used as received. $v(\mathrm{CO})$ Infrared spectra were recorded on a Bio-Rad Model FTS-185 spectrophotometer with sealed solution cells $(0.1 \mathrm{~mm})$ and $\mathrm{KBr}$ windows, NMR spectra on a Bruker AC 200 spectrometer $\left({ }^{1} \mathrm{H}\right.$ and ${ }^{13} \mathrm{C}$ relative to tetramethylsilane) and UV/VIS spectra on a GBC 918 spectrophotometer. Analyses of carbon, hydrogen and nitrogen contents were obtained with a Heraeus CHN analyzer.

\section{Preparations}

[N( $\left.\left(\mathbf{P P h}_{3}\right)_{2}\right]\left[\mathbf{N i}(\mathbf{C O})(\mathbf{S e P h})_{3}\right] \mathbf{1}$. Complex 1 was prepared and characterized according to the method reported earlier. ${ }^{12}$

$\left[\mathbf{N}\left(\mathbf{P P h}_{3}\right)_{2}\right]\left[\mathbf{N i}(\mathrm{CO})\left(2-\mathrm{SC}_{4} \mathrm{H}_{3} \mathrm{~S}\right)_{3}\right]$ 2. A solution containing $0.230 \mathrm{~g}(1 \mathrm{mmol})$ of di(2-thienyl) disulfide and $0.283 \mathrm{~g}(0.4$ $\mathrm{mmol})$ of $\left[\mathrm{N}\left(\mathrm{PPh}_{3}\right)_{2}\right]\left[\mathrm{HFe}(\mathrm{CO})_{4}\right]$ in thf $(5 \mathrm{~mL})$ was stirred at $15^{\circ} \mathrm{C}$ for $20 \mathrm{~min}$. The reaction was monitored immediately by IR. The spectrum ((thf): $\left.v(\mathrm{CO}) 2053 \mathrm{~s}, 1994 \mathrm{~s} \mathrm{~cm}^{-1}\right)$ was assigned to the formation of $f a c-\left[\mathrm{N}\left(\mathrm{PPh}_{3}\right)_{2}\right]\left[\mathrm{Fe}(\mathrm{CO})_{3}\left(2-\mathrm{SC}_{4} \mathrm{H}_{3} \mathrm{~S}\right)_{3}\right] .^{24} \mathrm{In}$ the same flask $0.2 \mathrm{mmol}$ of $[\mathrm{NiCp}(\mathrm{CO})]_{2}(0.061 \mathrm{~g})$ were added, followed by stirring at room temperature for $6 \mathrm{~h}$, and then diethyl ether $(10 \mathrm{~mL})$ was added to precipitate the dark green oily product. The reaction mixture was filtered, and the dark green oily product dried under $\mathrm{N}_{2}$ purge to afford $\left[\mathrm{N}\left(\mathrm{PPh}_{3}\right)_{2}\right]\left[\mathrm{Ni}(\mathrm{CO})\left(2-\mathrm{SC}_{4} \mathrm{H}_{3} \mathrm{~S}\right)_{3}\right] 2$ at $0{ }^{\circ} \mathrm{C}$ (yield $48 \%, 0.19 \mathrm{~g}$ ). The filtrate was dried under vacuum to afford $\left[\mathrm{FeCp}(\mathrm{CO})_{2^{-}}\right.$ $\left(2-\mathrm{SC}_{4} \mathrm{H}_{3} \mathrm{~S}\right)$ ]. When a thf solution of complex 2 is purged with ${ }^{13} \mathrm{CO}$ the IR $v(\mathrm{CO})$ peak at $2043 \mathrm{~cm}^{-1}$ immediately shifts to 1997 $\mathrm{cm}^{-1}$. The magnitude $\approx 46 \mathrm{~cm}^{-1}$ of the isotopic shift $(\Delta v(\mathrm{CO}))$ is consistent with the calculated position, based only on the difference in masses between ${ }^{12} \mathrm{CO}$ and ${ }^{13} \mathrm{CO}$. ${ }^{1} \mathrm{H}$ NMR $\left(\mathrm{CD}_{3} \mathrm{CN}\right): \delta 6.62(\mathrm{t}), 6.85$ (d) and 6.99 (d) $\left(\mathrm{C}_{4} \mathrm{H}_{3} \mathrm{~S}\right)$. UV/VIS (thf): $\lambda_{\max } / \mathrm{nm}\left(\varepsilon / \mathrm{M}^{-1} \mathrm{~cm}^{-1}\right) 363(6500)$ and 429(3747). Complex $\left[\mathrm{FeCp}(\mathrm{CO})_{2}\left(2-\mathrm{S}-\mathrm{C}_{4} \mathrm{H}_{3} \mathrm{~S}\right)\right]$ : IR $v(\mathrm{CO}) 2029 \mathrm{~s}, 1982 \mathrm{~s}$ (thf); 2035s, $1994 \mathrm{~s} \mathrm{~cm}^{-1}$ (hexane); ${ }^{1} \mathrm{H}$ NMR $\left(\mathrm{CD}_{2} \mathrm{Cl}_{2}\right) \delta 5.23$ (s) (Cp); Found C 60.35, H 4.18, N 1.60; Calc. for $\mathrm{C}_{49} \mathrm{H}_{39} \mathrm{NNiOP}_{2} \mathrm{~S}_{6} \mathrm{C} 59.62, \mathrm{H}$ $4.05, \mathrm{~N}, 1.44 \%$. The elemental analysis did not show good 
agreement with the calculated values because of the extreme thermal unstability.

$\left[\mathbf{N}\left(\mathbf{P P h}_{3}\right)_{2}\right]\left[\mathbf{N i}(\mathbf{C O})(\mathbf{S P h})(\mathbf{S e P h})_{2}\right]$ 3. The compounds $\mathbf{1}$ $(0.2 \mathrm{mmol}, 0.218 \mathrm{~g})$ and diphenyl disulfide $(0.2 \mathrm{mmol}, 0.044 \mathrm{~g})$ dissolved in $4 \mathrm{~mL}$ of thf were stirred under $\mathrm{N}_{2}$ at ambient temperature for $4 \mathrm{~h}$. The dark green brown solution was then filtered through Celite and hexane $(5 \mathrm{~mL})$ added to precipitate the air-sensitive, dark green solid $\left[\mathrm{N}\left(\mathrm{PPh}_{3}\right)_{2}\right][\mathrm{Ni}(\mathrm{CO})(\mathrm{SPh})$ $\left.(\mathrm{SePh})_{2}\right]$ 3. Yield $0.190 \mathrm{~g}(87 \%)$. Diffusion of hexane into a solution of complex 3 in thf at $-15^{\circ} \mathrm{C}$ for 4 weeks led to dark green crystals suitable for X-ray crystallography. IR (thf): $v(\mathrm{CO}) 2029 \mathrm{~s} \mathrm{~cm}^{-1} .{ }^{1} \mathrm{H}$ NMR $\left(\mathrm{CD}_{3} \mathrm{CN}\right): \delta 7.02-7.65(\mathrm{~m})(\mathrm{Ph})$ ${ }^{13} \mathrm{C}$ NMR $\left(\mathrm{CD}_{3} \mathrm{CN}\right): \delta 134.6,134.5,133.4,133.3,133.2,133.0$, $132.9,130.5,130.4,130.3,130.2$ and $130.1(\mathrm{Ph})$. UV/VIS (thf): $\lambda_{\max } / \mathrm{nm}\left(\varepsilon / \mathrm{M}^{-1} \mathrm{~cm}^{-1}\right) 555(1060), 416(2605)(\mathrm{sh}), 354(9433)(\mathrm{sh})$ and 320(18719). Found: C, 63.03; H, 4.48; N, 1.46. Calc. for $\mathrm{C}_{55} \mathrm{H}_{45} \mathrm{NNiOP}_{2} \mathrm{SSe}_{2}: \mathrm{C}, 63.12 ; \mathrm{H}, 4.33 ; \mathrm{N}, 1.34 \%$.

Reaction of $\left[\mathrm{N}\left(\mathrm{PPh}_{3}\right)_{2}\right]\left[\mathrm{Ni}(\mathrm{CO})(\mathrm{SePh})_{3}\right]$ with $\left[\mathrm{N}\left(\mathrm{PPh}_{3}\right)_{2}\right]-$ $\left[\mathrm{BH}_{4}\right]$ (and $\left[\mathrm{N}\left(\mathrm{PPh}_{3}\right)_{2}\right]\left[\mathrm{Ni}(\mathrm{CO})(\mathrm{SePh})_{3}\right]$ with sodium-benzophenone). A solution containing $0.218 \mathrm{~g}(0.2 \mathrm{mmol})$ of complex 1 and $0.222 \mathrm{~g}(0.4 \mathrm{mmol})$ of $\left[\mathrm{N}\left(\mathrm{PPh}_{3}\right)_{2}\right]\left[\mathrm{BH}_{4}\right]$ (the same stoichiometry is used for sodium-benzophenone) in thf $(10 \mathrm{~mL})$ was stirred under a $\mathrm{CO}$ atmosphere overnight (half hour for sodium-benzophenone) at room temperature. The solution was filtered to remove $\left[\mathrm{N}\left(\mathrm{PPh}_{3}\right)_{2}\right][\mathrm{SePh}]$ (or $\left.[\mathrm{Na}][\mathrm{SePh}]\right)$. The volume of the filtrate was then reduced to $3 \mathrm{~mL}$ and the dark green oily product $\left[\mathrm{N}\left(\mathrm{PPh}_{3}\right)_{2}\right]\left[\mathrm{Ni}(\mathrm{CO})_{3}(\mathrm{SePh})\right]$ precipitated by addition of hexane $(6 \mathrm{~mL})$. The thermally unstable product $\left[\mathrm{N}\left(\mathrm{PPh}_{3}\right)_{2}\right]\left[\mathrm{Ni}(\mathrm{CO})_{3}(\mathrm{SePh})\right]$ was isolated by removing the solvent (since decomposition occurred after prolonged vacuum the yield of the oily $\left[\mathrm{N}\left(\mathrm{PPh}_{3}\right)_{2}\right]\left[\mathrm{Ni}(\mathrm{CO})_{3}(\mathrm{SePh})\right]$ was difficult to determine). IR (thf): $v(\mathrm{CO}) 2031 \mathrm{w}$ and $1944 \mathrm{~s} \mathrm{~cm}^{-1} \cdot{ }^{13} \mathrm{C}$ NMR $\left(\mathrm{CD}_{3} \mathrm{CN}\right): \delta 199.72$ (s) (CO), 134.52, 133.14, 133.03, $130.65,130.44,130.18,129.28$ and $127.79(\mathrm{Ph}) .^{18,19}\left[\mathrm{~N}\left(\mathrm{PPh}_{3}\right)_{2}\right]-$ $\left[\mathrm{Ni}(\mathrm{CO})_{3}\left(2,4,6-\mathrm{Me}_{3} \mathrm{C}_{6} \mathrm{H}_{2} \mathrm{Se}\right)\right]: \quad \mathrm{IR}$ (thf): $\quad v(\mathrm{CO}) \quad 2028 \mathrm{w}$ and $1938 \mathrm{~s} \mathrm{~cm}^{-1}$.

[N( $\left.\left(\mathbf{P P h}_{3}\right)_{2}\right]\left[\mathbf{N i}(\mathbf{C O})(\mathbf{S P h})_{2}(\mathbf{S e P h})\right]$ 4. A solution containing $0.218 \mathrm{~g}(0.2 \mathrm{mmol})$ of complex 1 and $0.222 \mathrm{~g}(0.4 \mathrm{mmol})$ of $\left[\mathrm{N}\left(\mathrm{PPh}_{3}\right)_{2}\right]\left[\mathrm{BH}_{4}\right]$ in $\mathrm{MeCN}(3 \mathrm{~mL})$ was stirred under $\mathrm{CO}$ at ambient temperature for $5 \mathrm{~h}$ and then diethyl ether was added to precipitate the dark green oily product. The dark green oily product that was obtained upon removal of solvent from the resulting solution was extracted with $5 \mathrm{~mL}$ of degassed thf. The IR $v(\mathrm{CO})$ and ${ }^{13} \mathrm{C}$ NMR spectra ((thf): $v(\mathrm{CO}) 1944 \mathrm{vs}$ and $2031 \mathrm{w} \mathrm{cm}^{-1} ; \delta\left(\mathrm{CD}_{3} \mathrm{CN}\right): 199.72$ (s) (CO)) were assigned to the formation of $\left[\mathrm{N}\left(\mathrm{PPh}_{3}\right)_{2}\right]\left[\mathrm{Ni}(\mathrm{CO})_{3}(\mathrm{SePh})\right] .^{20}$ To the same flask a thf solution of $0.2 \mathrm{mmol}$ of $(\mathrm{PhS})_{2}(0.044 \mathrm{~g})$ was added slowly, followed by stirring at $5{ }^{\circ} \mathrm{C}$ for $3 \mathrm{~h}$. The dark green solution was then filtered and hexane added to precipitate the air-sensitive solid $\left[\mathrm{N}\left(\mathrm{PPh}_{3}\right)_{2}\right]\left[\mathrm{Ni}(\mathrm{CO})(\mathrm{SPh})_{2}(\mathrm{SePh})\right]$. Recrystallization from saturated thf solution with hexane diffusion gave dark green crystals of complex 4 at $-15^{\circ} \mathrm{C}$. IR (thf): $v(\mathrm{CO}) 2034 \mathrm{~s} \mathrm{~cm}^{-1} .{ }^{1} \mathrm{H}$ NMR $\left(\mathrm{CD}_{3} \mathrm{CN}\right): \delta 6.99-7.61(\mathrm{~m})(\mathrm{Ph}) .{ }^{13} \mathrm{C} \mathrm{NMR}\left(\mathrm{CD}_{3} \mathrm{CN}\right)$ : $\delta 134.5,133.3,133.1,133.0,130.5,130.4,130.3,130.1$ and 130.0 (Ph). UV/VIS (thf): $\lambda_{\max } / \mathrm{nm}\left(\varepsilon / \mathrm{M}^{-1} \mathrm{~cm}^{-1}\right) 537(1250)$ and 423(3837). Found: $\mathrm{C}, 65.62 ; \mathrm{H}, 4.66 ; \mathrm{N}, 1.53$. Calc. for $\mathrm{C}_{55} \mathrm{H}_{45} \mathrm{NNiOP}_{2} \mathrm{~S}_{2} \mathrm{Se}: \mathrm{C}, 66.08 ; \mathrm{H}, 4.54 ; \mathrm{N}, 1.40 \%$. Elemental analysis for $\mathrm{S}$ does not give good agreement with the calculated value because of extreme air-sensitivity.

Reaction of $\left[\mathrm{N}\left(\mathrm{PPh}_{3}\right)_{2}\right]\left[\mathrm{Ni}(\mathrm{CO})(\mathrm{SePh})_{3}\right]$ with bis(2-pyridyl) disulfide. Complex $1(0.218 \mathrm{~g}, 0.2 \mathrm{mmol})$ was added to bis(2-pyridyl) disulfide $(0.088 \mathrm{~g}, 0.4 \mathrm{mmol})$ in $\mathrm{MeCN}(6 \mathrm{~mL})$ at ambient temperature. After $3 \mathrm{~h}$ of stirring the green product $\left[\mathrm{N}\left(\mathrm{PPh}_{3}\right)_{2}\right]\left[\mathrm{Ni}\left(2-\mathrm{SC}_{5} \mathrm{H}_{4} \mathrm{~N}\right)_{3}\right]$ precipitated upon addition of diethyl ether. It was recrystallized from acetonitrile-diethyl ether. ${ }^{23}$ Yield $0.166 \mathrm{~g}(89 \%) .{ }^{1} \mathrm{H}$ NMR $\left(\mathrm{CD}_{3} \mathrm{CN}\right): \delta 12.27$ (br), 53.73 (br), 70.10 (br) and 96.47 (br) $\left(\mathrm{SC}_{5} \mathrm{H}_{4} \mathrm{~N}\right)$.
Table 2 Crystallographic data of complexes 3 and $\mathbf{4}$

\begin{tabular}{|c|c|c|}
\hline & 3 & 4 \\
\hline Formula & $\mathrm{C}_{55} \mathrm{H}_{45} \mathrm{NNiOP}_{2} \mathrm{SSe}_{2}$ & $\mathrm{C}_{55} \mathrm{H}_{45} \mathrm{NNiOP}_{2} \mathrm{~S}_{2} \mathrm{Se}$ \\
\hline$M$ & 1046.55 & 999.65 \\
\hline Crystal system & Triclinic & Triclinic \\
\hline Space group & $P \overline{1}$ & $P \overline{1}$ \\
\hline$a / \AA$ & $10.114(3)$ & $10.133(4)$ \\
\hline$b / \AA ̊$ & $15.504(3)$ & $15.499(3)$ \\
\hline$c / \AA ̊$ & $16.402(3)$ & $16.426(5)$ \\
\hline$a l^{\circ}$ & $73.35(2)$ & $73.39(2)$ \\
\hline$\beta /^{\circ}$ & $87.06(2)$ & $87.07(3)$ \\
\hline$\gamma /{ }^{\circ}$ & $87.50(2)$ & $87.51(3)$ \\
\hline$V / \AA^{3}$ & $2459.8(10)$ & $2467.7(13)$ \\
\hline$Z$ & 2 & 2 \\
\hline$\mu / \mathrm{mm}^{-1}$ & 2.021 & 1.319 \\
\hline$T /{ }^{\circ} \mathrm{C}$ & 22 & 22 \\
\hline$R$ & 0.0968 & 0.039 \\
\hline$R_{W F}$ & 0.1619 & 0.0895 \\
\hline $\begin{array}{l}\text { Independent } \\
\text { reflections }\end{array}$ & 6413 & 8672 \\
\hline
\end{tabular}

Reactions of sodium-benzophenone with $\left[\mathrm{N}\left(\mathrm{PPh}_{3}\right)_{2}\right][\mathrm{Ni}(2-$ $\left.\left.\mathrm{SC}_{5} \mathrm{H}_{4} \mathrm{~N}\right)_{3}\right]$ and $\left[\mathrm{N}\left(\mathrm{PPh}_{3}\right)_{2}\right]\left[\mathrm{Ni}(\mathrm{CO})_{3}\left(2-\mathrm{SC}_{5} \mathrm{H}_{4} \mathrm{~N}\right)\right]$ with diphenyl diselenide. $\left[\mathrm{N}\left(\mathrm{PPh}_{3}\right)_{2}\right]\left[\mathrm{Ni}\left(2-\mathrm{SC}_{5} \mathrm{H}_{4} \mathrm{~N}\right)_{3}\right](0.186 \mathrm{~g}, 0.2 \mathrm{mmol})$ dissolved in thf $(3 \mathrm{~mL})$ was stirred under a $\mathrm{CO}$ atmosphere, and a solution of sodium-benzophenone $(0.4 \mathrm{mmol})$ in thf added dropwise by cannula under a positive $\mathrm{CO}$ gas pressure at room temperature. $\left[\mathrm{N}\left(\mathrm{PPh}_{3}\right)_{2}\right][\mathrm{Cl}](0.23 \mathrm{~g}, 0.4 \mathrm{mmol})$ was then added. After stirring for $1 \mathrm{~h}$, the dark green solution was filtered to remove $\mathrm{NaCl}$ and the oily product $\left[\mathrm{N}\left(\mathrm{PPh}_{3}\right)_{2}\right]\left[\mathrm{Ni}(\mathrm{CO})_{3}(2-\right.$ $\left.\mathrm{SC}_{5} \mathrm{H}_{4} \mathrm{~N}\right)$ ] precipitated by addition of hexane. The IR spectrum ((thf): $v(\mathrm{CO}) 2037 \mathrm{w}$ and $1951 \mathrm{~s} \mathrm{~cm}^{-1}$ ) was identical to that of $\left[\mathrm{N}\left(\mathrm{PPh}_{3}\right)_{2}\right]\left[\mathrm{Ni}(\mathrm{CO})_{3}\left(2-\mathrm{SC}_{5} \mathrm{H}_{4} \mathrm{~N}\right)\right] .{ }^{19,20}$ The $\left[\mathrm{N}\left(\mathrm{PPh}_{3}\right)_{2}\right]\left[\mathrm{Ni}(\mathrm{CO})_{3}-\right.$ $\left.\left(2-\mathrm{SC}_{5} \mathrm{H}_{4} \mathrm{~N}\right)\right]$ was then redissolved in thf $(3 \mathrm{~mL})$. In the same flask $0.2 \mathrm{mmol}$ of diphenyl diselenide $(0.062 \mathrm{~g})$ was added, followed by stirring at room temperature for $10 \mathrm{~min}$, and then hexane $(5 \mathrm{~mL})$ was added to precipitate the dark green oily product $\left[\mathrm{N}\left(\mathrm{PPh}_{3}\right)_{2}\right]\left[\mathrm{Ni}(\mathrm{CO})_{3}(\mathrm{SePh})\right]$ (by ligand exchange) identified by IR ((thf): $v(\mathrm{CO}) 2031 \mathrm{w}$ and $1944 \mathrm{~s} \mathrm{~cm}^{-1}$ ). Addition of more diphenyl diselenide $(0.2 \mathrm{mmol}, 0.062 \mathrm{~g})$ to the same flask at room temperature results in the formation of $\left[\mathrm{N}\left(\mathrm{PPh}_{3}\right)_{2}\right]-$ $\left[\mathrm{Ni}(\mathrm{CO})(\mathrm{SePh})_{3}\right]$ (by oxidative addition) identified by IR, which was precipitated as a dark green solid on addition of hexane.

Reaction of $\left[\mathrm{N}\left(\mathrm{PPh}_{3}\right)_{2}\right]\left[\mathrm{Mn}(\mathrm{CO})_{5}\right]$ and $\left[\mathrm{N}\left(\mathrm{PPh}_{3}\right)_{2}\right][\mathrm{Ni}(\mathrm{CO})-$ $\left.(\mathrm{SePh})_{3}\right]$. A solution of $\left[\mathrm{N}\left(\mathrm{PPh}_{3}\right)_{2}\right]\left[\mathrm{Mn}(\mathrm{CO})_{5}\right](0.147 \mathrm{~g}$, $0.2 \mathrm{mmol})$ in thf $(2 \mathrm{~mL})$ was added dropwise to complex $\mathbf{1}$ $(0.218 \mathrm{~g}, 0.2 \mathrm{mmol})$ in thf solution under a $\mathrm{CO}$ atmosphere at ambient temperature. The mixture was stirred overnight at room temperature. The IR spectrum showed six new bands attributed to the well known carbonyl stretching modes of $\left[\mathrm{Ni}(\mathrm{CO})_{3}(\mathrm{SePh})\right]^{-}$((thf): $v(\mathrm{CO}) 2031 \mathrm{w}$ and $\left.1944 \mathrm{~s} \mathrm{~cm}^{-1}\right)$ and cis- $\left[\mathrm{Mn}(\mathrm{CO})_{4}(\mathrm{SePh})_{2}\right]^{-}$((thf): $v(\mathrm{CO}) 2041 \mathrm{~m}, 1969 \mathrm{~s}, 1950 \mathrm{~m}$ and $\left.1908 \mathrm{~m} \mathrm{~cm}^{-1}\right) .{ }^{18}$ No attempts were made to separate the complexes $\left[\mathrm{Ni}(\mathrm{CO})_{3}(\mathrm{SePh})\right]^{-}$and $c i s-\left[\mathrm{Mn}(\mathrm{CO})_{4}(\mathrm{SePh})_{2}\right]^{-}$.

\section{Crystallography}

Crystallographic data of complexes $\mathbf{3}$ and $\mathbf{4}$ are summarized in Table 2. The crystals of $\mathbf{3}$ and $\mathbf{4}$ are chunky. Each was mounted on a glass fiber and quickly coated in epoxy resin. Unit-cell parameters were obtained by least-squares refinement from 25 reflections. Diffraction measurements were carried out on a Nonius CAD 4 diffractometer with graphite-monochromated Mo-K $\alpha$ radiation. ${ }^{28}$ Least-squares refinement of the positional and anisotropic thermal parameters for all non-hydrogen atoms and fixed hydrogen atom contributions was based on $F^{2}$. A $\varphi$ scan absorption correction was made. The SHELXTL ${ }^{29}$ package of programs was employed, and atomic scattering factors were from ref. 30 . In the case of complex 3 one sulfur and one selenium atom $(\mathrm{X}(2)$ and $\mathrm{X}(3)$ as shown in Fig. 2) are 
found at disordered positions; in the case of $\mathbf{4}$ two sulfur atoms and one selenium atom are found at disordered positions and were refined by partial occupancies.

CCDC reference numbers 152484 and 152485.

See http://www.rsc.org/suppdata/dt/b0/b008902h/ for crystallographic data in CIF or other electronic format.

\section{Acknowledgement}

We gratefully acknowledge financial support from the National Science Council (Taiwan).

\section{References}

1 (a) S. W. Ragsdale and M. Kumar, Chem. Rev., 1996, 96, 2515; (b) S. A. Raybuck, N. R. Bastian, L. D. Zydowsky, K. Kobayashi, H. G. Floss, W. H. Orme-Johnson and C. T. Walsh, J. Am. Chem. Soc., 1987, 109, 3171; (c) W. Shin and P. A. Lindahl, J. Am. Chem. Soc., 1992, 114, 9718; (d) M. Kumar and S. W. Ragsdale, J. Am. Chem. Soc., 1992, 114, 8713; (e) D. Qui, M. Kumar, S. W. Ragsdale and T. G. Spiro, Science, 1994, 264, 817; $(f)$ M. J. Maroney, Curr. Opin. Chem. Biol., 1999, 3, 188.

2 Z. G. Hu, N. J. Spangler, M. E. Anderson, J. Q. Xia, P. W. Ludden, P. A. Lindahl and E. Münck, J. Am. Chem. Soc., 1996, 118, 830

3 D. Qiu, M. Kumar, S. W. Ragsdale and T. G. Spiro, J. Am. Chem. Soc., 1996, 118, 10429.

4 G. O. Tan, S. A. Ensign, S. Ciurli, M. J. Scott, B. Hedman, R. H. Holm, P. W. Ludden, Z. R. Korszun, P. J. Stephens and K. O Hodgson, Proc. Natl. Acad. Sci. U. S. A., 1992, 89, 4427.

5 (a) J. Q. Xia, J. Dong, S. K. Wang, R. A. Scott and P. A. Lindahl, J. Am. Chem. Soc., 1997, 119, 8301; (b) J. Q. Xia, Z. Hu, C. V. Popescu, P. A. Lindahl and E. Münck, J. Am. Chem. Soc., 1997, 119, 8301; (c) G. Davidson, S. B. Choudhury, Z. Gu, K. Bose, W. Roseboom, S. P. J. Albracht and M. J. Maroney, Biochemistry, 2000, 39, 7468.

6 A. Miedaner, C. J. Curtis, S. A. Wander, P. A. Goodson and D. L. DuBois, Organometallics , 1996, 15, 5185; C. Saint-Joly, A. Mari, A. Gleizes, M. Dartiguenave, Y. Dartiguenave and J. Galy, Inorg. Chem., 1980, 19, 2403; C. G. Pierpont and R. Eisenberg, Inorg. Chem., 1972, 11, 828 .

7 (a) F. Osterloh, W. Saak and S. Pohl, J. Am. Chem. Soc., 1997, 119 5648; (b) Y.-M. Hsiao, S. S. Chojnacki, P. Hinton, J. H. Reibenspies and M. Y. Darensbourg, Organometallics, 1993, 12, 870; (c) N. Baidya, M. M. Olmstead, J. P. Whitehead, C. Bagyinka, M. J. Maroney and P. K. Mascharak, Inorg. Chem., 1992, 31, 3612; $(d)$ D. Sellmann, D. Häussinger, F. Knoch and M. Moll, J. Am. Chem. Soc., 1996, 118, 5368; (e) C. A. Kelly, Q. G. Mulazzani, E. L. Blinn and M. A. J. Rodgers, Inorg. Chem., 1996, 35, 5122; $(f)$ Z. Lu and R. H. Crabtree, J. Am. Chem. Soc., 1995, 117, 3994; (g) S. A Macgregor, Z. Lu, O. Eisenstein and R. H. Crabtree, Inorg. Chem., 1994, 33, 3616; (h) P. J. Schbler, C. G. Riordan, I. A. Guzei and A. L. Rheingold, Inorg. Chem., 1998, 37, 4754; (i) G. L. Hillhouse and P. T. Matsunaga, Angew. Chem., Int. Ed. Engl., 1994, 33, 1748.
8 C. A. Marganian, H. Vazir, N. Baidya, M. M. Olmstead and P. K. Mascharak, J. Am. Chem. Soc., 1995, 117, 1584.

9 P. Stavropoulos, M. C. Muetterties, M. Carrie and R. H. Holm, J. Am. Chem. Soc., 1991, 113, 8485.

10 T. Yamamura, S. Sakurai, H. Arai and H. Miyamae, J. Chem. Soc., Chem. Commun., 1993, 1656.

11 D. H. Nguyen, H.-F. Hsu, M. Millar, S. A. Koch, C. Achim, E. L. Bominaar and E. Münck, J. Am. Chem. Soc., 1996, 118, 8963.

12 W.-F. Liaw, Y.-C. Horng, D.-S. Ou, C.-Y. Chiang, G.-H. Lee and S.-M. Peng, J. Am. Chem. Soc., 1997, 119, 9299.

13 (a) R. H. Holm, P. Kennepohl and E. I. Solomon, Chem. Rev. 1996, 96, 2239; (b) T. C. Stadtman, Annu. Rev. Biochem., 1996, 65, 83; (c) A. Böck, K. Forchhammer, J. Heider, W. Leinfelder, G. Sawers, B. Veprek and F. Zinoni, Mol. Microbiol., 1991, 5, 515.

14 W.-F. Liaw, C.-H. Chen, C.-M. Lee, G.-Y. Lin, C.-Y. Ching, G.-H. Lee and S.-M. Peng, J. Chem. Soc., Dalton Trans., 1998, 353; W.-F. Liaw, C.-M. Lee, L. Horng, G.-H. Lee and S.-M. Peng, Organometallics, 1999, 18, 782.

15 E. D. Schermer and W. H. Baddley, J. Organomet. Chem., 1971, 27, 83; H. Schumann, A. M. Arif, A. L. Rheingold, C. Janiak, R. Hoffmann and N. Kuhn, Inorg. Chem., 1991, 30, 1618.

16 A. F. Bartlone, M. J. Chetcuti, P. E. Fanwick and K. J. Haller, Inorg. Chem., 1993, 32, 1435.

17 J. M. O'Connor and C. P. Casey, Chem. Rev., 1987, 87, 307.

18 W.-F. Liaw, C.-Y. Chuang, W.-Z. Lee, C.-K. Lee, G.-H. Lee and S.-M. Peng, Inorg. Chem., 1996, 35, 2530.

19 G.-M. Bodner, Inorg. Chem., 1975, 14, 1932; C. A. Tolman, J. Am. Chem. Soc., 1970, 92, 2953; W. Kaschube, K.-R. Pörschke, W. Bonrath, C. Krüger and G. Wilke, Angew. Chem., Int. Ed. Engl., 1989, 28, 772 .

20 W. Kleimann, K.-R. Pörschke and G. Wilke, Chem. Ber., 1985, 118, 323; M. Zhou and L. Andrews, J. Am. Chem. Soc., 1998, 120, 11499.

21 W.-F. Liaw, C.-H. Chen, G.-H. Lee and S.-M. Peng, Organometallics, 1998, 17, 2370.

22 T. L. James, L. Cai, M. C. Muetterties and R. H. Holm, Inorg. Chem., 1996, 35, 4148.

23 S. G. Rosenfield, H. P. Berends, L. G. Gelmimi, D. W. Stephan and P. K. Mascharak, Inorg. Chem., 1987, 26, 2792.

24 W.-F. Liaw, S.-J. Chiou, G.-H. Lee and S.-M. Peng, Inorg. Chem., 1998, 37, 1131; W.-F. Liaw, C.-H. Lai, M.-H. Chiang, C.-K. Hsieh, G.-H. Lee and S.-M. Peng, J. Chin. Chem. Soc. (Taipei), 1993, 40, 437.

25 W.-F. Liaw, M.-H. Chiang, C.-J. Liu and P.-J. Harn, Inorg. Chem., 1993, 32, 1536.

26 C. K. Johnson, ORTEP II, Report ORNL-5138, Oak Ridge National Laboratory, Oak Ridge, TN, 1976.

27 S. G. Rosenfield, W. H. Armstrong and P. K. Mascharak, Inorg. Chem., 1986, 25, 3014.

28 A. C. T. North, D. C. Philips and F. S. Mathews, Acta Crystallogr., Sect. A, 1968, 24, 351 .

29 G. M. Sheldrick, SHELXTL, Program for Crystal Structure Determination, Siemens Analytical X-Ray Instruments Inc., Madison, WI, 1994.

30 International Tables for X-Ray Crystallography, Kynoch Press, Birmingham, 1974, vol. 4, Table 2.2B. 